
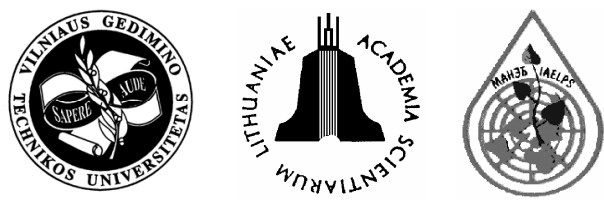

\title{
MODELLING OF Cu, Ni, Zn, Mn AND Pb TRANSPORT FROM SOIL TO SEEDLINGS OF CONIFEROUS AND LEAFY TREES
}

\author{
Edita Baltrènaité ${ }^{1}$, Donatas Butkus ${ }^{2}$ \\ Dept of Environmental Protection, Vilnius Gediminas Technical University, \\ Sauletekio al. 11, LT-10223 Vilnius, Lithuania \\ E-mail: ${ }^{1}$ edita@ap.vgtu.lt; ${ }^{2} a a k @ a p . v g t u . l t$
}

Submitted 7 Sept. 2007; accepted 20 Sept. 2007

\begin{abstract}
Transport of trace metals (TMs) from the soil to a plant involves chemical, physical and biological processes (such as diffusion, adsorption, absorption, growth of a plant, transpiration rate, etc.) in the soil, the soil rhizosphere and in the plant itself. Because of the complexity of these processes and external factors (e.g. weather conditions, biotic factors, type of substrate, etc.) the processes are difficult to describe by mathematical formulas. Modelling of TMs transport to plants is even more complex than that of organic contaminants because, contrary to organic contaminants, TMs are essential for plant growth, metabolism, enzyme activity, etc. The octanol-water partitioning coefficient for TMs in plants gives only limited information about their accumulation, therefore, other coefficients, such as bioconcentration and translocation coefficients, must be incorporated. The aim of this work was to simulate transport of $\mathrm{TMs}(\mathrm{Zn}, \mathrm{Pb}, \mathrm{Cu}, \mathrm{Ni}$ and $\mathrm{Mn})$ from the soil to tree seedlings by adapting a generalized model of contaminant uptake by plants. The model applied for transport of TMs from the soil to trees was created by Hung and Muckay. When employing this model for modelling transport of TMs from the soil, amended with industrial sewage sludge, to seedlings of coniferous and leafy trees, some adjustments were made by evaluating the equilibrium partitioning coefficient of TMs between octanol and water $\left(\mathrm{K}_{\mathrm{ow}}\right)$; by introducing the equilibrium partitioning coefficient of TMs in the soil and water $\left(\mathrm{K}_{\mathrm{d}}\right)$, which depends on the soil $\mathrm{pH}$ and the amount of organic matter; by introducing the coefficient $\left(\mathrm{K}_{\mathrm{T}}\right)$ of TMs solubility in water as well as by introducing corrective coefficients. When using the Hung and Muckay's model of the transport of trace metals from the soil to tree seedlings, the results of modelling differed approximately by $6 \%$ in leaves, $5 \%$ in the stem and $8 \%$ in roots as compared with those of measurements.
\end{abstract}

Keywords: trace metals, modelling, transport, seedlings, pine, birch, black alder.

\section{Introduction}

Sewage sludge is one of the major waste management problems in many countries, especially in those following EU regulations that prohibit disposal in landfills. Other sewage sludge treatment methods, such as energy production, recycling, thermal destruction, treatment to reduce or remove hazardous constituents, are suggested, however, spreading of sewage sludge on natural and arable soils have received more attention.

Forest soils are more suitable for receiving sewage sludge for several reasons: (i) they have no direct link to human food chain [1]; (ii) well managed sewage sludge can improve the forest soil quality because of high amount of organic matter [1, 2]; (iii) adding of stabilized sludge can stimulate both height and diameter of trees (conifers) [2, 3] and increase survival when they are transplanted outdoors [2]; (iv) because of large biomass and long vegetation period, forest trees attract attention for possibility to uptake metals [4].

Although only some tree species (e.g. willows and osiers) are considered to be suitable for effective uptake of metals, there is a growing demand to use a wide range of tree species as a part of an integrated management of soil reclamation and forest regeneration following sewage sludge amendment $[4,5]$. Not much information is available about the metal uptake by other tree species, such as pine, birch, alder, etc.

The uptake of trace metals (TMs) by trees is a complex process and its efficiency varies with different tree species, the soil properties $(\mathrm{pH}$, redox potential, particle size and organic matter content), substrate conditions, sewage sludge age, metal content, metal availability, etc. [4-7]. Furthermore, it is reported that metals may have different affect on trees, especially on tree seedlings. There are evidences that these elements may inhibit root growth [8,9], decrease availability of essential elements [10], modify morphology and architecture [8], inhibit protein and enzyme functions [11, 12], reduce plant ability to access and transport soil resources (e.g. water) [13] or have no visual affect on pine, birch and black alder seedlings [6]. With a notable increase within the first year of growth $[14,15]$ a decline of metal concentration in different tree species was recorded after three years [16]. 
For effective planning, design and application of trace metal bioaccumulation in trees, mathematical models have emerged as a valuable tool, which, after extensive adaptation, will enable to evaluate economic value of tree bioaccumulation.

Transport of TMs from the soil to a tree covers a set of chemical, physical and biological processes in the soil, the tree and an interaction zone between the tree roots and the soil, e.g. diffusion of TMs in the soil and tree, adsorption and absorption, partitioning of TMs between air, water, soil and roots, flow with transpiration flow, etc. The complexity of processes, the impact of external factors, such us climate conditions, type of substratum, etc. make simulation of this process more difficult.

Models to simulate uptake of TMs by plants as distinct from organics uptake must take into consideration the fact that some of TMs are essential for plant organism to stimulate growth, metabolism, enzyme activities, etc. This could be partially assessed with equilibrium partitioning coefficient for TMs between octanol and water $\left(K_{o w}\right)$. Bioaccumulation and translocation coefficients could also be valuable in TMs transport model.

This study presents a model of TMs transport from the industrial sewage sludge, spread on the soil, to seedlings of trees, based on the simplified model of the transport of contaminants from the soil to plants designed by Hung and Muckay [17]. The model evaluates the transport of TMs to plants from two media - the soil and air and computes concentrations of contaminants in three plant compartments: roots, the stem and leaves. The uptake of TMs from the soil to plants depends on the coefficients of partitioning of contaminants in various media (the soil, water, transpiration flow, etc.) as well as on metabolic rate, steady coefficients of contaminant concentration, and diffusion.

The objective of this study is to apply the model of Hung and Muckay for evaluating the transport of TMs from the soil to seedlings of coniferous and leafy trees.

\section{Methods}

To model TMs uptake, seedlings of pine (Pinus sylvestris), birch (Betula pendula) and black alder (Alnus glutinosa) grown on an experimental site in Panevėžys region (at $\mathrm{E} 024^{\circ} 34^{\prime} 38.8^{\prime}$ 'latitude and $\mathrm{N} 55^{\circ} 43^{\prime} 31.6^{\prime}$ ', longitude, Lithuania) were selected (Fig 1).

In 1998 the experimental site was amended with industrial wastewater sludge and a year later seedlings of trees were planted there. A detailed description of the investigated site, the soil and tree sampling is given in the previous publication [18].

The Hung and Muckay's model [17] applied in this study computes transport of TMs from the soil to plant roots, from the roots - to the stem, from the stem - to the leaves, from the leaves - to the air and backwards. The transport and transformation of TMs in the soil and plants is defined by TMs equilibrium partitioning in different media, the metabolic rate, diffusion coefficients, and the growth rate of different plant compartments. Variable and input values are presented in Table 1.
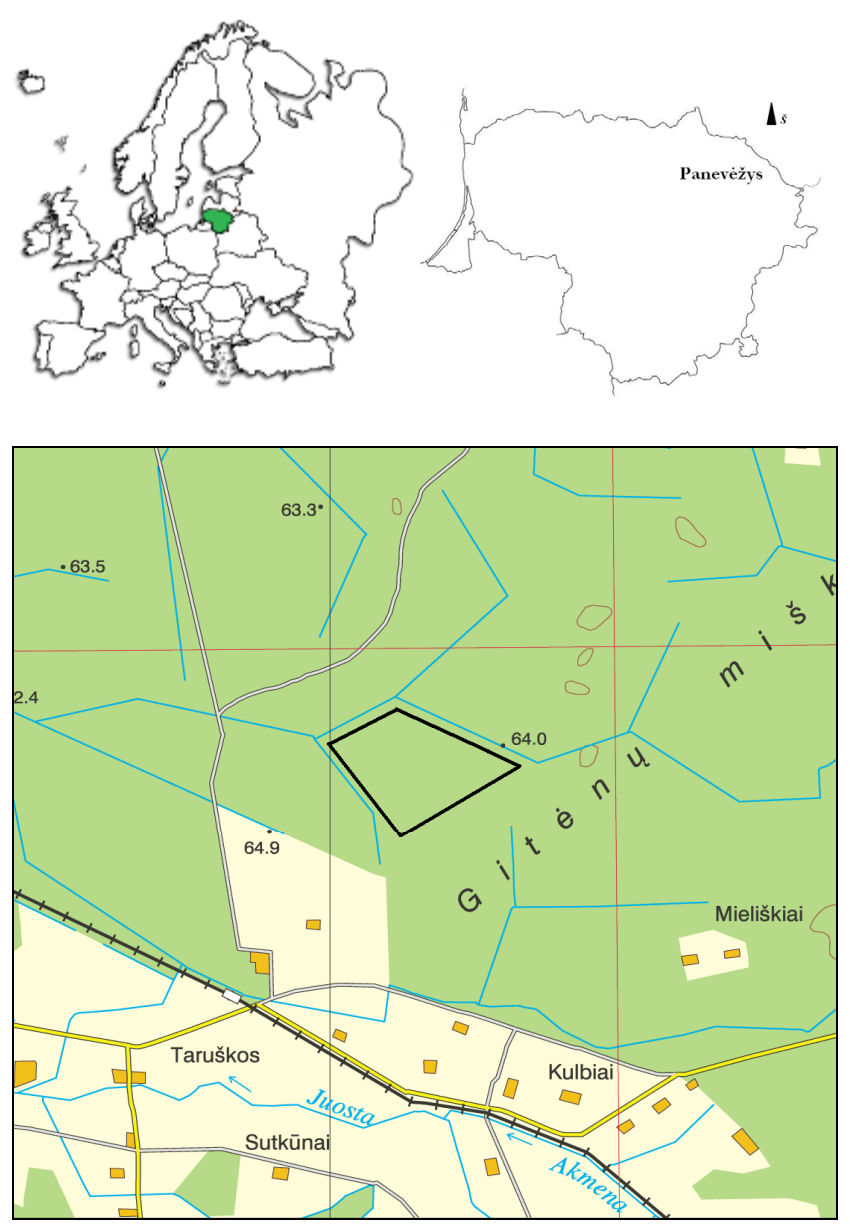

(LTD BK $50000-V$ ○ NŽT, 2004, HNIT-BALTIC GIS, 2005, M 1:28000)

Fig 1. Experimental site for industrial sewage sludge utilization in Gitėnai forest of Taruškos forestry located in Panevėžys region (Lithuania)

Equations involved in the model for computing concentrations in roots $\left(C_{\text {root }}\right)$, the stem $\left(C_{\text {stem }}\right)$ and leaves $\left(C_{\text {leaves }}\right)$ are given below. The description and the units of variables are given in Table 1.

$$
\begin{aligned}
& C_{\text {leaves }}=\left(\frac{B_{e r} \cdot B_{r s} \cdot B_{s l} \cdot K_{l w} \cdot C_{\text {soil }}}{K_{e w}}+\frac{B_{a l} \cdot K_{l w} \cdot C_{a}}{K_{a w}}\right) \cdot \frac{M_{T M}}{\rho_{\text {leaves }}}, \\
& C_{\text {stem }}=\left(\frac{B_{e r} \cdot B_{r s} \cdot K_{s t w} \cdot C_{\text {soil }}}{K_{e w}}+\frac{B_{a l} \cdot B_{l s} \cdot K_{s t w} \cdot C_{a}}{K_{a w}}\right) \cdot \frac{M_{T M}}{\rho_{s t e m}}, \\
& C_{\text {root }}=\left(\frac{B_{e r} \cdot K_{r w} \cdot C_{\text {soil }}}{K_{e w}}+\frac{B_{a l} \cdot B_{l s} \cdot B_{s r} \cdot K_{r w} \cdot C_{a}}{K_{a w}}\right) \cdot \frac{M_{T M}}{\rho_{\text {root }}}
\end{aligned}
$$

The steady state of contaminant concentrations in different plant compartments is calculated using equations (4), (5) and (6):

$$
\begin{gathered}
A_{\text {leaves }}=1-e^{-0.639 \cdot \frac{t}{T_{L}}}, \\
A_{\text {stem }}=1-e^{-0.639 \cdot \frac{t}{T_{S}}},
\end{gathered}
$$


Table 1. Input and computed parameters to model TM uptake by a tree seedling

\begin{tabular}{|c|c|c|}
\hline Parameter & MARKING & Unit \\
\hline Leaf area & $L_{P}$ & $\mathrm{~m}^{2}$ \\
\hline Transpiration rate & $Q$ & $\mathrm{~m}^{3} \cdot \mathrm{h}^{-1}$ \\
\hline \multicolumn{3}{|l|}{ Growth and metabolism } \\
\hline Growth rate of leaves & $\tau_{L G}$ & $\mathrm{~h}^{-1}$ \\
\hline Growth rate of stem & $\tau S_{G}$ & $\mathrm{~h}^{-1}$ \\
\hline Growth rate of roots & $\tau R_{G}$ & $\mathrm{~h}^{-1}$ \\
\hline Metabolism rate for leaves & $\tau_{L M}$ & $\mathrm{~h}^{-1}$ \\
\hline Metabolism rate for stem & $\tau_{S M}$ & $\mathrm{~h}^{-1}$ \\
\hline Metabolism rate for roots & $\tau_{R M}$ & $\mathrm{~h}^{-1}$ \\
\hline Density of leaves & $\rho_{\text {lap }}$ & $\mathrm{kg} \cdot \mathrm{m}^{-3}$ \\
\hline Density of stem & $\rho_{\text {kam }}$ & $\mathrm{kg} \cdot \mathrm{m}^{-3}$ \\
\hline Density of roots & $\rho_{\check{s} a k}$ & $\mathrm{~kg} \cdot \mathrm{m}^{-3}$ \\
\hline Exposure duration of TM & $t$ & $\mathrm{H}$ \\
\hline Molar mass of TM & $M_{T M}$ & $\mathrm{~g} \cdot \mathrm{mol}^{-1}$ \\
\hline Concentration of TM in air & $C_{a}$ & $\mathrm{mmol} \cdot \mathrm{m}^{-3}$ \\
\hline \multicolumn{3}{|l|}{ Equilibrium partitioning coefficients } \\
\hline Carbohydrate-water & $K_{c w}$ & dimensionless \\
\hline Octanol-water & $K_{\text {ow }}$ & dimensionless \\
\hline Air-water & $K_{a w}$ & dimensionless \\
\hline Leaves-water & $K_{l w}$ & dimensionless \\
\hline Stem-water & $K_{s t w}$ & dimensionless \\
\hline Root-water & $K_{r w}$ & dimensionless \\
\hline Soil-water & $K_{e w}$ & dimensionless \\
\hline Sap-water & $K_{x w}$ & dimensionless \\
\hline Octanol-air & $K_{\text {oa }}$ & dimensionless \\
\hline Diffusion fraction in xylem flow & $\Phi$ & $\mathrm{h}$ \\
\hline Characteristic time through cuticle & $T \_k u$ & $\mathrm{~h}$ \\
\hline Characteristic time through air & T_sr.or & $\mathrm{h}$ \\
\hline \multicolumn{3}{|l|}{ Uptake ratios } \\
\hline Uptake ratio from air to leaves & $B_{a l}$ & dimensionless \\
\hline Uptake ratio from leaves to stem & $B_{l s}$ & dimensionless \\
\hline Uptake ratio from stem to leaves & $B_{s l}$ & dimensionless \\
\hline Uptake ratio from stem to roots & $B_{s r}$ & dimensionless \\
\hline Uptake ratio from roots to stem & $B_{r s}$ & dimensionless \\
\hline Uptake ratio from soil to roots & $B_{e r}$ & dimensionless \\
\hline Total concentration of $\mathrm{TM}$ in soil & $C_{\text {soil }}$ & $\mathrm{mg} \cdot \mathrm{kg}^{-1}$ \\
\hline
\end{tabular}


Table 2. Specific values for TMs and molar masses

\begin{tabular}{|c|c|c|c|c|c|c|c|}
\hline \multirow{2}{*}{ Parameter, units } & \multicolumn{6}{|c|}{ Trace metals } & \multirow{2}{*}{ References } \\
\hline & $\mathrm{Cu}$ & $\mathbf{N i}$ & Mn & $\mathbf{P b}$ & $\mathrm{Cr}$ & Zn & \\
\hline Molar mass, $\mathrm{g} \cdot \mathrm{mol}$ & 63.5 & 59 & 55 & 207.2 & 52 & 65.3 & \\
\hline $\begin{array}{l}K_{d} \text { which depends on soil acidity/ alkalinity } \\
\text { (values at } \mathrm{pH}=4.5-6.0,1 \cdot \mathrm{kg}^{-1}\end{array}$ & - & $12-650$ & $1126-2063$ & 4219-12904 & $16.8-360$ & $16-530$ & {$[19,20]$} \\
\hline $\log K_{d}$ for soil, $1 \cdot \mathrm{kg}^{-1}$ & $0.1-3.6$ & $1.0-3.8$ & - & $0.7-5.0$ & $-0.7-4.7$ & $-1.0-5.0$ & [21] \\
\hline \multirow{2}{*}{$K_{o w}$} & 200 & 120 & 140 & 40 & 200 & 110 & \multirow{2}{*}{ [22] } \\
\hline & \multicolumn{6}{|c|}{$15-200$} & \\
\hline $\begin{array}{l}\text { Concentration of trace metals in soil amen- } \\
\text { ded with industrial sewage sludge, } \mathrm{mg} \cdot \mathrm{kg}^{-1}\end{array}$ & 143 & 46.5 & 698 & 1000 & 107 & 471 & [6] \\
\hline
\end{tabular}

$$
A_{\text {root }}=1-e^{-0.639 \cdot \frac{t}{T_{R}}}
$$

where $T_{L}, T_{S}, T_{R}$ - the total half-life for leaves, the stem and roots, respectively, $\mathrm{h}$.

The model does not involve contaminant-specific processes, therefore, the transport of different contaminants can be simulated.

Seeking to adapt the model for TMs uptake by tree seedlings, the model has been adjusted:

- values of equilibrium partitioning coefficient between octanol and water $\left(K_{o w}\right)$ were specified for TMs;

- partitioning coefficient between the soil and water $\left(K_{d}\right)$ was introduced with TMs specific values. $K_{d}$ depends on $\mathrm{pH}$ and the amount of soil organic matter;

- coefficient $\left(K_{T}\right)$ of TMs solubility in soil solution was introduced;

- corrective coefficients were introduced.

Table 2 gives parameters with TMs specific values based on references.

This paper presents simulation of TMs transport from the soil, amended with sewage sludge, to the roots, stem and leaves of a coniferous and leafy tree seedling.

The investigated territory represents an area far away from technogenic TMs sources, and thus concentrations of TMs in the air as well as their transport from the air to a tree through leaves and needles are considered negligible

Densities used for simulation are $863 \mathrm{~kg} \cdot \mathrm{m}^{-3}$ for pinewood, $878 \mathrm{~kg} \cdot \mathrm{m}^{-3}$ - for birch wood and $827 \mathrm{~kg} \cdot \mathrm{m}^{-3}$ for black alder wood [23]. The mass of sewage sludge volume accounted for $1520 \mathrm{~kg} \cdot \mathrm{m}^{-3}$. The volumes of roots, the stem and leaves were experimentally determined and constituted $0.001 \mathrm{~m}^{3}, 0.002 \mathrm{~m}^{3}$ and $0.00013 \mathrm{~m}^{3}$, respectively for leafy tree seedlings, and $0.001 \mathrm{~m}^{3}, 0.003 \mathrm{~m}^{3}$ and $0.00013 \mathrm{~m}^{3}$, respectively, for coniferous tree seedlings.

The metabolism rate in roots, the stem and leaves was left as suggested by the model authors because these values were used when assessing physiological processes in maples [24].

When modelling the transport of TMs to tree seedlings, the concentration of TMs in the soil was equalled to the sum of concentration of TMs in sewage sludge and background concentration of TMs in the surrounding soil (Table 2).
Although the layer of sewage sludge spread on the soil was up to $3 \mathrm{~cm}$, the results of other researchers suggest that during one year bioavailable forms of TMs, where the major mass of large and, in particular, fine roots playing the main role in nutrients uptake are concentrated, has reached the soil depth of 10-20 cm [6].

A part of both bioavailable and potentially bioavailable forms of the total TMs concentration was theoretically determined from previous investigation and accounted for $0.3\left(K_{T}\right)[6,25]$.

The duration of modelling is 6 years, but the focus is not on the time period, but on a steady state of TMs concentrations in tree seedlings computed using equations 4 , 5 and 6 . Previous studies suggested that the most active uptake of TMs by tree seedlings occured within the first year after tree planting [6].

\section{Results and discussion}

Figures 2 and 3 present the results of the simulation adjusted with corrective coefficients in comparison to the experimental data with the values of standard errors. Bars denoting standard errors represent heterogeneity of sewage sludge also resulted in high variations of TMs content in both the soil and trees.

Simulation results in coniferous (pine) tree compartments varied: from 25.9 to $66.5 \mathrm{mg} \cdot \mathrm{kg}^{-1}$ for $\mathrm{Zn}$; from 2.22 to $9.59 \mathrm{mg} \cdot \mathrm{kg}^{-1}$ for $\mathrm{Cu}$; from 28.8 to $179.1 \mathrm{mg} \cdot \mathrm{kg}^{-1}$ for $\mathrm{Mn}$; from 15.9 to $20.9 \mathrm{mg} \cdot \mathrm{kg}^{-1}$ for $\mathrm{Ni}$; and from 0.41 to $3.27 \mathrm{mg} \cdot \mathrm{kg}^{-1}$ for $\mathrm{Pb}$. Simulation results for $\mathrm{Pb}$ and $\mathrm{Zn}$ showed a tendency to decrease from root upwards, whereas in case of $\mathrm{Mn}$, the tendency was quite the opposite. Only a slight difference was found for Ni concentration within tree compartments, whereas the highest concentration of $\mathrm{Cu}$ was simulated in the coniferous tree stem.

Corrective coefficients used to adapt the model to experimental results varied from 1.0 to 3.0 for uptake to roots, from 0.1 to 0.6 for transport from roots to the stem and from 0.1 to 9.0 - for uptake from the stem to needles.

Simulation results in leafy (birch and black alder) tree compartments varied: from 141 to $270 \mathrm{mg} \cdot \mathrm{kg}^{-1}$ for $\mathrm{Zn}$; from 2.51 to $11.45 \mathrm{mg} \cdot \mathrm{kg}^{-1}$ for $\mathrm{Cu}$; from 84.7 to $118.8 \mathrm{mg} \cdot \mathrm{kg}^{-1}$ for $\mathrm{Mn}$; from 19.2 to $24.2 \mathrm{mg} \cdot \mathrm{kg}^{-1}$ for $\mathrm{Ni}$ and from 0.01 to $3.30 \mathrm{mg} \cdot \mathrm{kg}^{-1}$ for $\mathrm{Pb}$. $\mathrm{Mn}$ and $\mathrm{Zn}$ showed the same tendency as observed in the experimental data to increase from roots upwards, whereas both simulation 
results and experimental data for $\mathrm{Pb}$ showed the opposite trend. Speaking of $\mathrm{Cu}$, the highest concentration was found in the stem, whereas the difference between $\mathrm{Ni}$ concentrations in compartments varied only slightly within the range of standard error values.

Corrective coefficients for leafy tree simulation ranged from 1.0 to 3.0 for root uptake; from 0.25 to $0.35-$ for stem uptake and from 0.5 to 4.0 for uptake of TMs to leaves.

Simulation results showed that applicability of Hung and Muckay's model to simulate TMs transport from the soil to the compartments of tree seedlings is highly dependent on values of many processes occurring in the soil, the plant itself and also the interaction zone of soilplant and corrective coefficients.

The affinity between corrective coefficients was found for some TMs: for leafy trees - between $\mathrm{Zn}$ and $\mathrm{Cu}$ (1.5) and $\mathrm{Ni}$ and $\mathrm{Mn}$ (3.0) for uptake by roots and between $\mathrm{Pb}, \mathrm{Mn}$ and $\mathrm{Cu}$ - for uptake from roots to the stem (0.25). In simulation of coniferous trees, some affinity was determined between corrective coefficients for $\mathrm{Ni}$ and $\mathrm{Mn}$ (3.0) for uptake by roots; between $\mathrm{Zn}$ and $\mathrm{Pb}$ (0.1) for uptake from roots to the stem; for $\mathrm{Zn}, \mathrm{Pb}$ and $\mathrm{Cu}$ (0.1) for uptake from the stem to needles. Such approximate values of corrective coefficients between some of the TMs may show affinity in uptake of these TMs by tree seedlings.
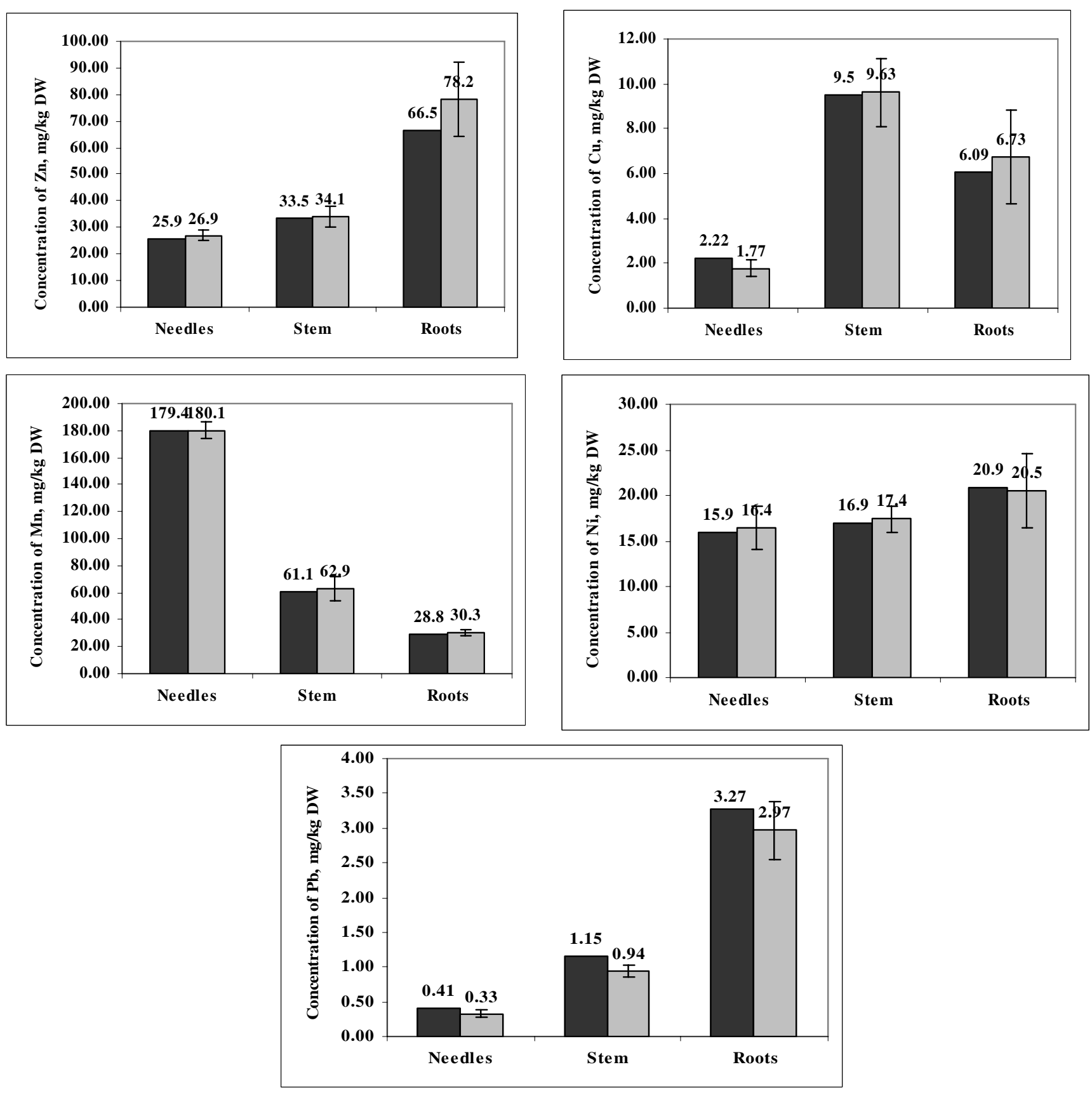

Fig 2. Concentration of TMs in three compartments of a coniferous tree (pine): simulation results are presented in black, and experimental results - in grey (the bars denote $\pm \mathrm{SE}, n=4$ ) 

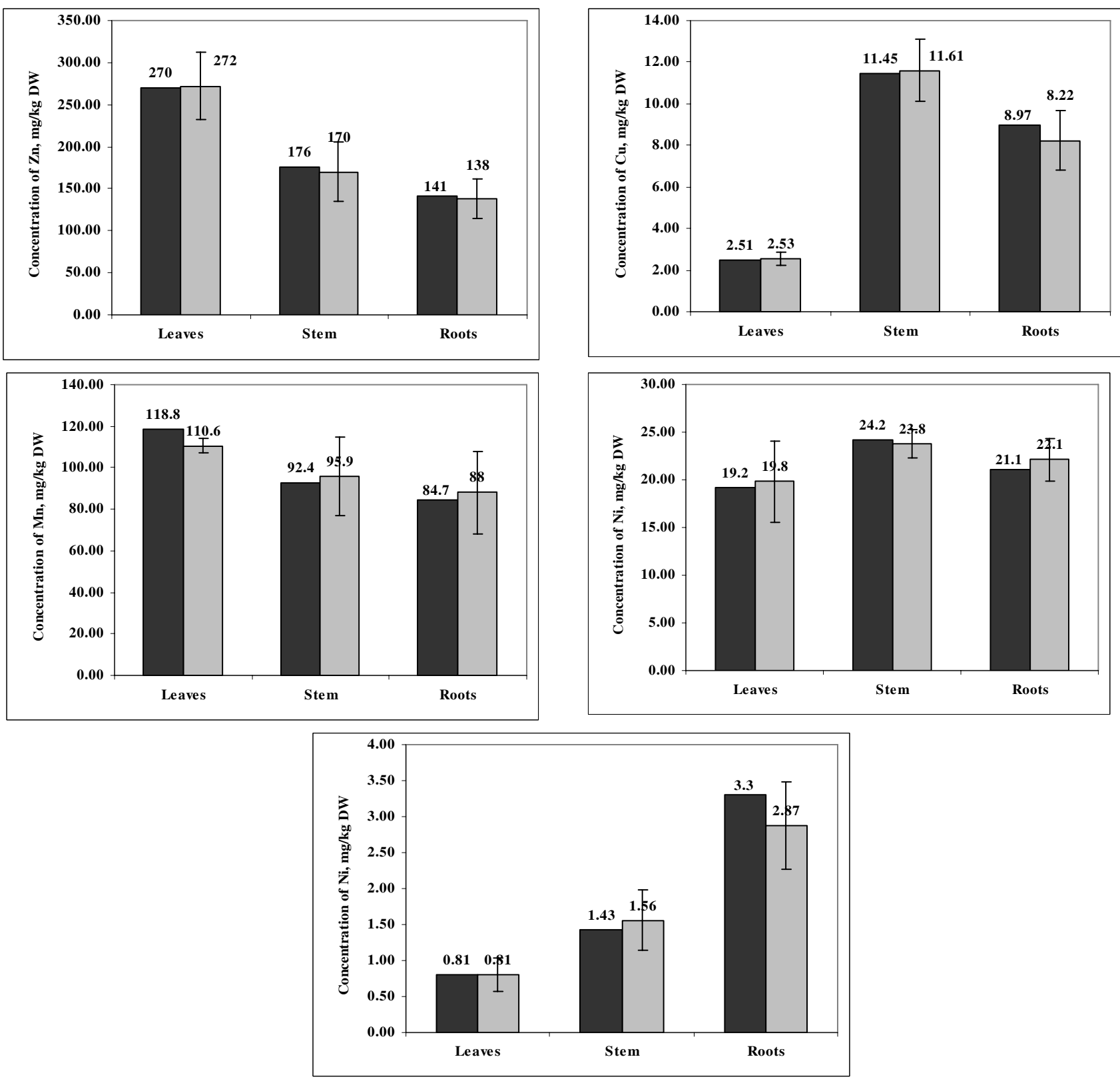

Fig 3. Concentration of TMs in three compartments of a leafy tree (birch and black alder): simulation results are in black, and experimental results - in grey (the bars denote $\pm \mathrm{SE}, n=4$ )

Mean values of corrective coefficients were 2.0 for root uptake, 0.28 - for stem uptake and 2.9 - for leave uptake in leafy trees and 1.8 for root uptake, 0.31 - for stem uptake and 2.56 - for needle uptake in coniferous trees.

\section{Conclusions}

1. When using the Hung and Muckay's model of the transport of contaminants from the soil to plants, adapted to tree seedlings under experimental conditions, the results of modelling differed by around $6 \%$ in leaves, $5 \%$ in stems and $8 \%$ in roots as compared with those of the experimental data.

2. The applied model is easy to adapt to particular conditions because it uses coefficients the values of which can be changed according to the required conditions (e.g. for different types of trees, simulation period, changes in soil properties, etc.)

3. More data on TMs uptake by trees is required to prove suitability of the Hung and Muckay's model for TMs uptake by higher plants. It is also very important to determine the volume of tree roots, the stem and leaves and the metabolism rate of different types and age of seedlings.

\section{Acknowledgements}

The authors would like to thank Dr Valentinas Kadūnas from the Institute of Geology and Geography (Lithuania) for valuable discussions and suggestions during the experimental work. 
This scientific research is funded under the implementation of the COST program activity No 859 Phytotechnologies to promote sustainable land use and improve food safety and the project Contaminants in the system soil-plant: contaminants transport, accumulation and soil remediation funded by the Agency for International Science and Technology Development Programs in Lithuania.

\section{References}

1. HORSWELL, J.; WEITZ, H. J.; PERCIVAL, H. J.; SPEIR, T. W. Impact of heavy metal-amended sewage sludge on forest soils as assessed by bacterial and fungal biosensors. Biol. Fertil. Soils, 2006, Vol. 26, p 569-576.

2. LAMBERT, D. H.; WEIDENSAUL, T. C.; BORGER, D. C. and RHODE, L. H. Use of sewage sludge for forest-tree seedling production. Project Summary. EPA, 1985. 8 p.

3. SALCEDO-PEREZ, E.; VAZQUEZ-ALARCON, A.; KRISHNAMURTHY, L.; ZAMORA-NATERA, F.; HERNANDEZ-ALVAREZ, E.; MACIAS, R. R. Evaluation of sewage sludge as an organic fertilizer in volcanic soils of agriculture and forestall use in Jalisco, Mexico. Intersciencia, 2007, Vol. 32 (2), p 115-120.

4. PULFORD, I. D. and DICKINSON, N. M. Phytoremediation technologies using trees. In Trace Elements in the Environment: Biogeochemistry, Biotechnology, and Bioremediation. M. N. V. Prasad, Kenneth S. Sajwan, Ravi Naidu (eds.), 2005, CRC, p 375-395.

5. FRENCH, CH. J.; DICKINSON, N. M.; PUTWAIN, PH. D. Woody biomass phytoremediation of contaminated brownfield land. Environmental Pollution, 2006, Vol. 141, p 387-395.

6. KATINAS, V. et al. Processes of chemical element dispersion and redistribution in environment using wastewater sludge for recultivation of woodcuttings areas. Geologija, 2002, Vol. 38, p 3-11.

7. BUTKUS, D.; BALTRE்NAITĖ, E.; KAZIUKONIENĖ, D. Estimation of heavy metal accumulation in tree rings. Environmental Engineering (Aplinkos inžinerija), 2002, Vol. X, No. 4, p 156-160.

8. ARDUINI, I.; GODBOLD, D. L.; ONNIS, A. Influence of copper on root growth and morphology of Pinus pinea L. and Pinus pinaster Ait. seedlings. Tree Physiology, 1995, Vol. 15, p 411-415.

9. HARTLEY, J.; CAIRNEY, J. W.; FREESTONE, P.; WOODS, P.; MEHARG, A. A. The effects of multiple metal contamination on ectomycorrhizal Scots pine (Pinus sylvestris) seedlings. Environmental Pollution, 1999, Vol. 106, p 413-424.

10. KABATA-PENDIAS, A.; PENDIAS, H. Trace elements in soils and plants. CRC Press, Boca Raton, FL, 1992.
11. CAKMAK, I. Possible roles of zinc in protecting plant cells from damage by reactive oxygen species. New Phytologist, 2000, Vol. 146, p 185-205.

12. MAKSYMIEC, W. Effect of copper on cellular processes in higher plants. Photosynthetica, 1997, Vol. 34, p 321342 .

13. BARCELÓ, J.; POSCHENRIEDER, CH. Plant water relations as affected by heavy metal stress: a review. Journal of Plant Nutrition, 1990, Vol. 13, p 1-37.

14. PULFORD, I. D.; RIDDELL-BLACK, D. and STE WART, C. Heavy metal uptake by willow clones from sewage sludge-treated soil: the potential for phytoremediation. Int. J. Phytoremediation, 2002, Vol. 4, p 59-72.

15. HAMMER, D.; KAYSER, A. and KELLER, C. Phytoextraction of $\mathrm{Cd}$ and $\mathrm{Zn}$ with Salix viminalis in field trials. Soil Use Management, 2003, Vol. 19, p 187-192.

16. MORIN, M. D. Heavy metal concentrations in 3-year-old trees grown on sludge-amended surface mine spoil. In Proceedings of a Symposium on Surface Mining, Hydrology, Sedimentology and Reclamation, Groves, D. H. (ed.), Lexington, KY: OES Press, 1981, p 297.

17. HUNG, H.; MACKAY, D. A novel and simple model of the uptake of organic chemicals by vegetation from air and soil. Chemosphere, 1997, Vol. 35, p 959-977.

18. BUTKUS, D.; BALTRĖNAITĖ, E. Accumulation of sewage sluoge-derived heavy metals in tree seedlings. Ekologija, 2007 (in press).

19. PART 5. Chemical-Specific Parameters, 1996, p 133160. Available from Internet: <www.epa.gov/superfund/resources/soil/>.

20. JOSE, L.; PILLAI, V. N. R. Transition metal complexes of polymeric amino ligands derived from thriethyleneglycol dimethacryle crosslinked polyacrylamides. Journal of Applied Polymer Science, 1996, Vol. 60, p 1855-1865.

21. ALLISON, J. D.; ALLISON, T. L. MINTEQA2. Geochemical speciation workshop. Allison geoscience consultants, Inc., Buford, GA. 2004. Available from Internet: $<$ http://www.epa.gov/athens/wwqtsc/courses/wasp7/toxicants/>.

22. TURNER, A.; MAWJI, E. Octanol-solubility of dissolved and particulate trace metals in contaminated rivers: implications for metal reactivity and availability. Environmental Pollution, 2005, Vol. 135(2), p 235-244.

23. VERBYLA, V. Miškininko žinynas. Vilnius: Mokslas, 1990. 480 p.

24. TSIROS, I. X.; AMBROSE, R. B.; CHRONOPOULUSERELI, A. Air-vegetation-soil partitioning of toxic chemicals in environmental simulation modelling. Global Nest: Int. J., 1999, Vol. 1(3), p 177-184.

25. Verma, P.; George, K. V.; Singh, H. V.; Singh, S. K.; JUWARKAR, A. and SINGH, R. N. Modeling rhizofiltration: heavy metal uptake by plant roots. Environmental Modeling and Assessment, 2006, Vol. 11, p 387-394. 
Cu, Ni, Zn, Mn IR Pb PERNAŠOS IŠ DIRVOŽEMIO İ SPYGLIUOČIŲ IR LAPUOČIŲ MEDŽIŲ SODINUKUS MODELIAVIMAS

E. Baltrènaitė, D. Butkus

Santrauka

Sunkiụu metalų (SM) pernaša iš dirvožemio ị augalą apima cheminių, fizikinių ir biologinių procesų (tokių, kaip difuzija, adsorbcija, absorbcija, augalo augimas, transpiracijos greitis ir kt.), vykstančių dirvožemyje, rizosferos zonoje ir pačiame augale. Dèl šių procesų sudètingumo ir išorinių veiksnių poveikio (pvz., klimato sąlygos, biotiniais veiksniai, substrato rūšis ir kt. juos sudėtinga aprašyti matematinemis išraiškomis. Metalų pernašos i augalus modeliavimas yra dar sudėtingesnis negu organinių teršalų, nes, kitaip nei organiniai teršalai, sunkieji metalai yra svarbūs augalų augimui, medžiagụ apykaitai, fermentų veiklai ir kt. Sunkiujjų metalų pasiskirstymo tarp oktanolio ir vandens koeficientas suteikia nedaug informacijos apie sunkiujų metalų kaupimosi augaluose pobūdi, todèl būtina įtraukti papildomus koeficientus, pvz., biologinio pasisavinimo ir translokacijos koeficientus. Šio darbo tikslas buvo sumodeliuoti sunkiujų metalu $(\mathrm{Zn}, \mathrm{Pb}, \mathrm{Cu}, \mathrm{Ni}$ ir Mn) pernašą iš dirvožemio į medžio sodinukus, pritaikant Hung ir Muckay sukurtą teršalų pernašos į augalus modelį. Pritaikant modelį sunkiujų metalų pernašai iš dirvožemio su paskleistu pramoniniu nuotekų dumblu i spygliuočių ir lapuočių medžių sodinukus atlikta keletas korekcijų, ivvertinant sunkiujų metalu pusiausvyros pasiskirstymo tarp oktanolio ir vandens koeficientą $\left(K_{o w}\right)$, sunkiujų metalų pusiausvyros tarp dirvožemio ir vandens koeficientą $\left(K_{d}\right)$, kuris priklauso nuo dirvožemio $\mathrm{pH}$ ir organinès medžiagos kiekio, ir įtraukiant sunkiujų metalų tirpumo vandenyje koeficientą $\left(K_{T}\right)$, taip pat pataisos koeficientus. Pritaikius Hung ir Muckay modeli sunkiujų metalų pernašai iš dirvožemio į medžių sodinukus, modeliavimo rezultatai nuo matavimo rezultatų skyrèsi apie $6 \%$ lapuose, $5 \%$ kamiene ir $8 \%$ šaknyse.

Reikšminiai žodžiai: sunkieji metalai, modeliavimas, pernaša, sodinukai, pušis, beržas, juodalksnis.

\section{МОДЕЛИРОВАНИЕ ПЕРЕНОСА Cu, Ni, Zn, Mn И Pb ИЗ ПОЧВЫ В САЖЕНЦЫ ХВОЙНЫХ И ЛИСТВЕННЫХ ДЕРЕВЬЕВ}

\section{Э. Балтренайте, Д. Буткус}

Резюме

Перенос тяжелых металлов из почвы в дерево сопровождается многими физическими, химическими и биологическими процессами (такими, как диффузия, адсорбция, абсорбция, рост дерева, скорость транспирации и др.), происходящими в почве, зоне ризосферы и самом дереве. Эти процессы математически трудно описать из-за их сложности и влияния внешних факторов (например, климатических условий, биотических факторов, вида субстрата и др.). Моделирование переноса металлов из почвы в дерево является более сложным, чем переноса органических загрязнителей, поскольку они иначе влияют на рост растений, кругооборот веществ, действие ферментов и др. Например, распределение тяжелых металлов между октиловым спиртом и водой дает неполную информацию о накоплении тяжелых металлов в растениях, поэтому необходимо ввести дополнительные коэффициенты, например, коэффициенты биологического освоения и транслокации. Целью настоящей работы было применение модели Ганга и Маккея (Hung and Muckay), созданной для определения переноса загрязняющих веществ в растения, для моделирования переноса тяжелых металлов из почвы с добавленным в нее промышленным илом в саженцы хвойных и лиственных деревьев. Существующая модель откорректирована путем введения коэффициентов равновесия тяжелых металлов между октиловым спиртом и водой $\left(\mathrm{K}_{\text {оw }}\right)$, между почвой и водой $\left(\mathrm{K}_{\mathrm{d}}\right)$, зависящих от кислотности почвы и количества органического вещества; коэффициента, определяющего разбавляемую часть тяжелых металлов $\left(\mathrm{K}_{\mathrm{T}}\right)$, а также некоторых поправочных коэффициентов. После применения экспериментально установленных коэффициентов и поправок в модели Ганга и Маккея оказалось, что результаты моделирования отличались от результатов измерения на $6 \%$ в листъях, на $5 \%$ - в стволе и на $6 \%$ - в корнях саженцев деревьев.

Ключевые слова: тяжелые металлы, моделирование, перенос, саженцы, сосна, береза, черная ольха.

Edita BALTRÉnAITĖ. Dr, Assoc Prof, Dept of Environmental Protection, Vilnius Gediminas Technical University (VGTU).

Doctor of Technological Sciences (environmental engineering and landscape management), VGTU, 2007. Membership: International Water Association (IWA), European Society for Soil Conservation (ESSC), International Society for Environmental Information Sciences, (ISEIS), Young European Biotech Network (YEBN). Research interests: trace metals in the soil and trees, waste management, cleaner production, environmental management and environmental education.

Donatas BUTKUS. Dr Habil, Prof, Dept of Environmental Protection, Vilnius Gediminas Technical University (VGTU). Doctor Habil of Science (environmental engineering), VGTU, 1999. Membership: a member of International Academy of Ecological and Life Protection Sciences. Publications: author of more than 200 research papers, co-author of the monograph Geophysical problems of atmospheric krypton-85 (in Russian and English). Research interests: radioactive gases, self-cleaning of the atmosphere, ionizing radiation; consequences of the Chernobyl accident; environment physical pollution (ionic and non-ionic radiation, noise and vibration). 